\title{
A Study of Environmental ethics of disabled students
}

\author{
Dr. N. M Tajpuria ${ }^{1}$
}

\section{ABSTRACT:}

Education is Basic tool to aware people about the environment. Education for environment is now a day's necessary. Education for the environment encourages behaviors which are environmentally sustainable and also helps ensure that future producers and decision makers demonstrate sensitivity towards environment.

The study was conducted to compare Environmental Ethics of Locomotors and sighted male and female disabled student.

The present study aims to know environmental ethics to disabled students (50 locomotors and 50sighted disabled) and further sample divided in to gender. The disabled students were selected by using random sampling technique from National Association for the Blind Idar Branch Dist. Sabarkantha, North Gujarat which is the branch in district only for disabled Environmental ethics scale developed by Hassen Taj was used to measure environmental ethics. "T" test was used to find out significance difference. The study indicates the difference in environmental ethics of locomotors and sighted disabled students.

On the basis of the findings of the study, investigation indicated that locomotors disabled students have more environmental ethics than sighted. So it should be noticed by the teachers of this unique university that sighted students are unable to visualized whole things which are present in their environment because of their visual disability.

Keywords: Environment, Students

\section{INTRODUCTION:}

Today Environment has become an international point to discuss in the word. Every human being lives in environment, both effects to each other. Every human being has the right to decent life, but today there are elements in our environment tend to militate against the attainment and enjoyment of such a life. The exacerbation of the pollution of environment can cause untold misery. Unhappiness and suffering to human beings crop up simply because of our lack of concern for the common good and the absence of a sense of responsibility and ethics for sustaining a balanced ecosystem.

\footnotetext{
${ }^{1}$ Head Department of Psychology, Arts \& Commerce College, Khedbrahma, Dist. S.K. North Gujarat
} 


\section{A Study of Environmental ethics of disabled students}

If we are to aspire to a better quality of life- one which will ensure freedom from want, from disease and from fear itself, then we must all join hands to stem the increasing modification of the earth. Besides we should teach them how to save the environment from further degradation, and help make it a healthier and progressive place to live in; this springs from a strong sense of social responsibility. Hence, it becomes obligatory on the part of each individual citizen to develop environmental ethics that, while we aspire for the good life, should not sacrifice the future of the generations to come (Minda C \& Sutaria 1990).

\section{Environmental Ethics:}

Environmental ethics is the scientific study of various issues related to the rights of the individual with regard to the environment. It is the moral relationship of human beings with the dos and don'ts of the human being to the environment. It is concerned with the dos and don'ts human being to the environment. It deals with ecological rights of all creatures present today as well as those that will follow on the earth. Ethical standards are necessary for long-term conservation and maintenance of nature and its resources.

Environment ethics refers to the responsibility to understand the environmental consequences of our consequences of our consumption and need to recognize our individual and social responsibility to conserve natural resources and protect the earth for future generations.

Environmental ethics is the discipline that studies the moral relationship of human beings to and also the value and moral status of the environment and its nonhuman contents. This entry covers : (1) the challenge of environmental (i.e., human centeredness) embedded in traditional western ethical thinking; (2) the early development of the discipline in the 1960s and 1970s; (3) the connection of deep ecology, feminist environmental ethics and social ecology to politics; (4) the attempt to apply traditional ethical theories, including consequentially, deontology and virtue ethics to support contemporary environmental concerns; and (5) the focus of environmental literature on wilderness and possible future developments of the discipline.

\section{Importance of the study:}

Education is the basic tool to aware people about their environment. Every human being is depending on environment for their basic need of good air, water and food. We can see that our environment is going to be disablement elements as right way. So climate is shifting from its natural settings. As result, new diseases are taking birth. Uncertainty of rain is taking place. Low production in field of agriculture is going on. To maintain our environment, we have be aware to the people. People have to acquire basic environmental functions in order to grow food, find water and protect themselves from the climate. We still need knowledge of science and technology to shape and perpetuate the modern world. In field of environmental education, some researchers have been conducted earlier. Thomas (2002) on Environmental ethics, Gayford (1996) on Environmental education in schools, Meyers (2004) on Environmental values and ethics, Neter (1989) on Hispanic cultural influence on environmental concern. Gifford (1982) on 


\section{A Study of Environmental ethics of disabled students}

environmental attitudes, Patel (1995) and Bhattacharya (1996) on environmental awareness, Larsen (1996) on environmental virtue ethics. All these studies have done on teachers, students and General people, but researches on special students about environment is neglected. Disabled is also human being since when every human being would not be aware about protection of their environment, then environment can not be balanced and protected. So this study tries to investigate the environmental ethics of disabled (locomotors and sighted) students of National Association for the blind branch-Idar (SK) which is first unique branch of the world only for disabled. The study aims at offering meaningful suggestions for improving the environmental ethics among the disabled students.

\section{Operational Definition:}

Environmental ethics: Environmental ethics refer to the responsibility to understand the environmental consequence of our consumption and need to recognize our individual and social responsibility to conserve natural resources and protect the earth for the future generations.

\section{Disability:}

Locomotors disability means disability of the bones, joints, muscles leading to substantial restriction of the movement of the limbs of any form of cerebral palsy. Person with sighted are those with impairment of visual functioning even after treatment or standard refracting correction but who uses or is potentially capable of using vision for the planning of execution of a task with appropriate assertive device. (Rao, 2007)

\section{OBJECTIVES OF THE STUDY:}

The study was conducted by taking following objectives:

- To compare Environmental Ethics of Sighted male and female disabled students.

- To compare Environmental Ethics of Locomotors male and female disabled students.

- To compare Environmental Ethics of Locomotors and sighted disabled student.

\section{HYPOTHESIS OF THE STUDY:}

- There is no significance difference between Environmental Ethics of Locomotors disabled students in relation to their gender.

- There is no significance difference between Environmental Ethics of Sighted disabled students in relation to their gender.

- There is no significance difference between Environmental Ethics of Locomotors and Sighted disabled students. 


\section{Sample :}

The study was carried out on 100 disabled students selected from various Centers of National Association for the blind branch-Idar (SK) The sample consisted of 50 locomotors and 50 sighted disabled, which are divided into male and female in both category. The students were selected for to investigate by using simple Random Sampling technique.

\section{Tools :}

Environmental ethics scale developed by Hassen Taj (2001) was used to measure Environmental Ethics of disabled students in present study.

\section{Analysis of Data:}

The quantitative data collected through the questionnaire was analyzes by using SPSS Package. Statistical techniques like Mean, Standard Deviation and T-test were used for analysis of the data.

\section{RESULT AND DISCUSSION :}

Table No. 1, Significance difference between the means of Environmental Ethics of Sighted male and female disabled students.

\begin{tabular}{|c|c|c|c|c|}
\hline Disability & N & Mean & SD & t-value \\
\hline Sighted male & 27 & 103.86 & 9.50 & 0.74 \\
\cline { 1 - 4 } Sighted female & 23 & 105.66 & 9.91 & \\
\hline
\end{tabular}

The t-value indicates that there was no significance difference between their Environmental Ethics of Sighted male and female disabled students.

Table No. 2, Significance difference between the means of Environmental Ethics of Locomotors male and female disabled student.

\begin{tabular}{|c|c|c|c|c|}
\hline Disability & N & Mean & SD & t-value \\
\hline Locomotors male & 23 & 114.20 & 8.90 & 4.12 \\
\hline Locomotors female & 27 & 105.12 & 9.65 & \\
\hline
\end{tabular}

*Significant at 0.01 level of significance 
The calculated t-value (4.12) with the degree of freedom is more than the tabulated value at 0.01 levels. Therefore, the Hypothesis there is no significance difference between Environmental Ethics of locomotors male and female disabled students, is rejected and it can be concluded that Locomotors male disabled students have more Environmental Ethics than female Locomotors disabled students.

Table No. 3, Significance difference between the means of Environmental Ethics of Locomotors and Sighted disabled

\begin{tabular}{|c|c|c|c|c|}
\hline Disability & N & Mean & SD & t-value \\
\hline Locomotors & 50 & 111.12 & 9.07 & $3.11^{*}$ \\
\hline Sighted & 50 & 105.80 & 11.12 & \\
\hline
\end{tabular}

The calculated t-value (3.11) with the degree of freedom is more than the tabulated values at 0.01 levels. Therefore, the Hypothesis There is no significance difference between Environmental Ethics of locomotors and Sighted disabled, is rejected and it can be concluded that locomotors disabled students have more Environmental Ethics than Sighted disabled students.

\section{MAJOR FINDINGS:}

The following are the major findings of the investigation:

- Sighted male and female disabled students do not differ in their environmental ethics.

- There is a Significance difference between the means of Environmental Ethics of Locomotors male and female disabled student.

- There is a significance difference between the Environmental Ethics of Locomotors and sighted disabled students.

On the basis of the findings of the study, investigation indicated that locomotors disabled students have more environmental ethics than sighted. So it should be noticed by the teachers of this unique university that sighted students are unable to visualized whole things which are present in their environment because of their visual disability. Although both categories are under the deprivation but sighted disabled students are more deprived so the teachers should treated specially with them about environmental crisis by Environmental Education because Education about the environment - a basic knowledge and understanding of environmental process (atmospheric, hydrologic, geomorphic and ecological) and concept (green house effect, water conservation, soil erosion and habitat destruction, etc.). Knowledge about human environmental behavior is an indispensable component of the branch of Environmental Education. So by this process, it would be possibility for developing high level environmental ethics in sighted disabled students. 


\section{A Study of Environmental ethics of disabled students}

\section{References :}

Bhattacharya, G.C. (1996). A Study of Environmental Awareness among Primary Grade Giral Students and their Parents in Varanasi. Indian Educational Abstracts, Issue 6, Jan, 1999, 65.

Das, M. (1980). Education of Exceptional Children, Cuttak: Takshysils.

Ellen S. and Berger G. (1983) Education and acquisition of psychological Matunty. In d Mc clellend (Ed.) The Development - Social Maturity, New York, Irvington, 46-73

Gifford, R., Hay, R. \& Boros, K. (1982). Individual Differences in Environmental Attitudes. Journal of Environmental Educational, 4 (2), 19-23

Gayford, Chris. (1996). Environmental Education in Schools. An Alternative Framework; Canadian Journal of Environmental Education. Volume 1, P.105. http://kankyoinstitute.lit.kohan_v.ac.jp/-taniguchi/ eng/ee_fieldwork_chris. Pdf

Hallahan, D.P. and Kaunfman, J.M. (1978). Exceptional Children : Introduction to Special Education, New Jersy, Prenticehall

Minda, C. \& Sutaria (1990). The Role of Value Education in Environmental Education in Source book in Environmental Education for Secondary school Teachers, ed. R. C. Sharma and Marlec. Tam, Bangkok : UNESCO Principal Regional Office for asia and Pacific. 